\title{
A POSSIBLE SIGHT RECORD OF THE BLACK-FOOTED FERRET IN SASKATCHEWAN
}

WILLIAM B. PRESTON, Manitoba Museum of Man and Nature, 190 Rupert Avenue, Winnipeg, Manitoba, R3B 0N2.

On 17 June 1979, accompanied by my seven-year-old daughter, I visited Chimney Coulee, four miles $(6.4 \mathrm{~km})$ north of Eastend, Saskatchewan. At approximately $1100 \mathrm{hr}$. MDT, I was walking up the coulee on a dirt track, near the cairn, when my attention was attracted by the movement of a small mammal leaping in weasel fashion through low shrubbery (approximately $0.5 \mathrm{~m}$ in height) to my right, between my daughter and myself (Figure 1). As it crossed the track about $20 \mathrm{~m}$ in front of me 1 recognized it as a black-footed ferre (Mustela nigripes). The animal dis appeared into aspen bush on th north side of the track. My daughter who did not see it, possibly ha frightened it toward me.

The animal I saw was somewha larger, more heavily built, and had shorter tail than a long-tailed wease It was very pale in colour, much pale than the palest long-tailed weasel i the collections of the Manitob Museum of Man and Nature, and th

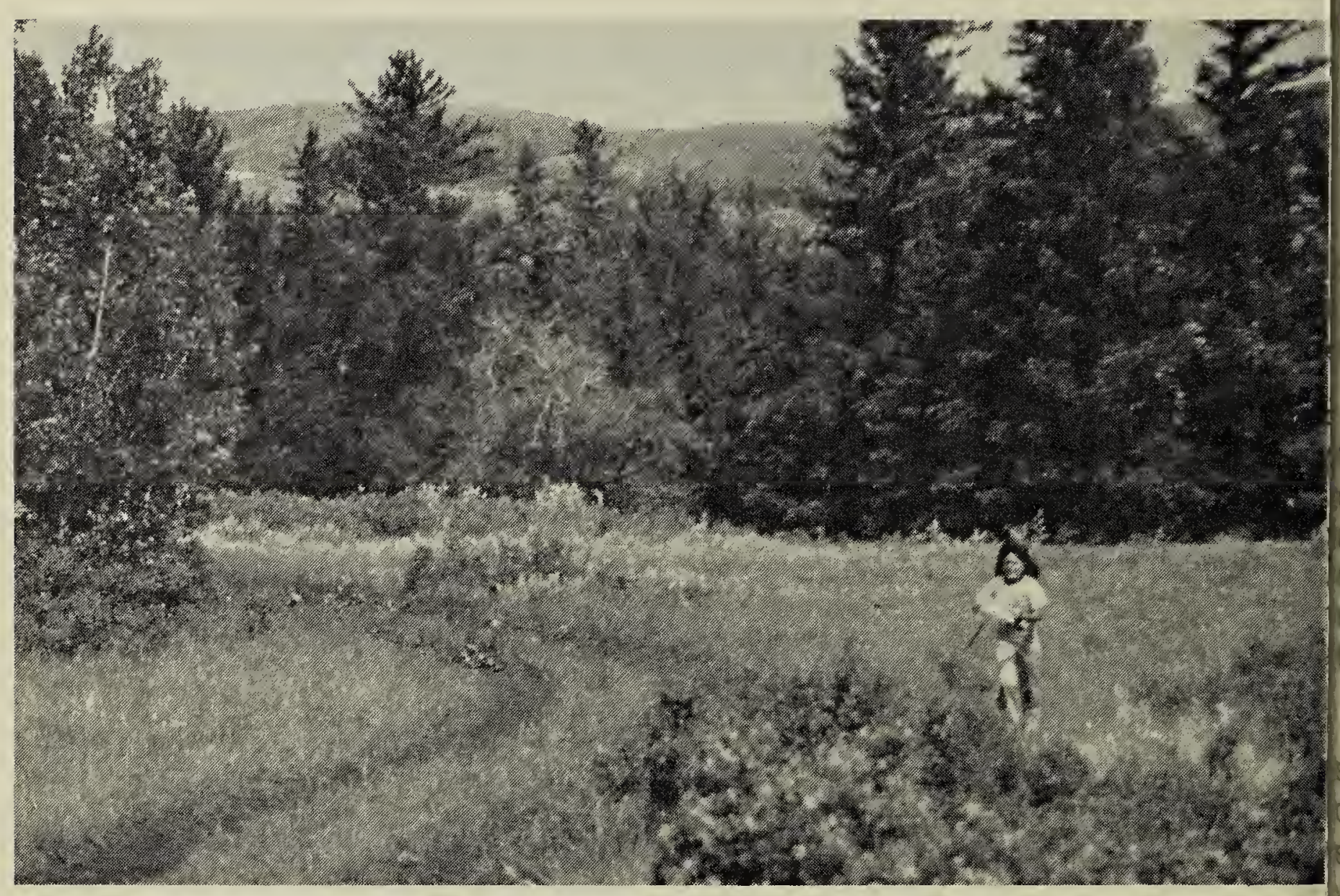

Figure 1. The ferret was first seen in the low shrubbery, right foreground, a few minutes before this photograph was made with a telephoto lens. 


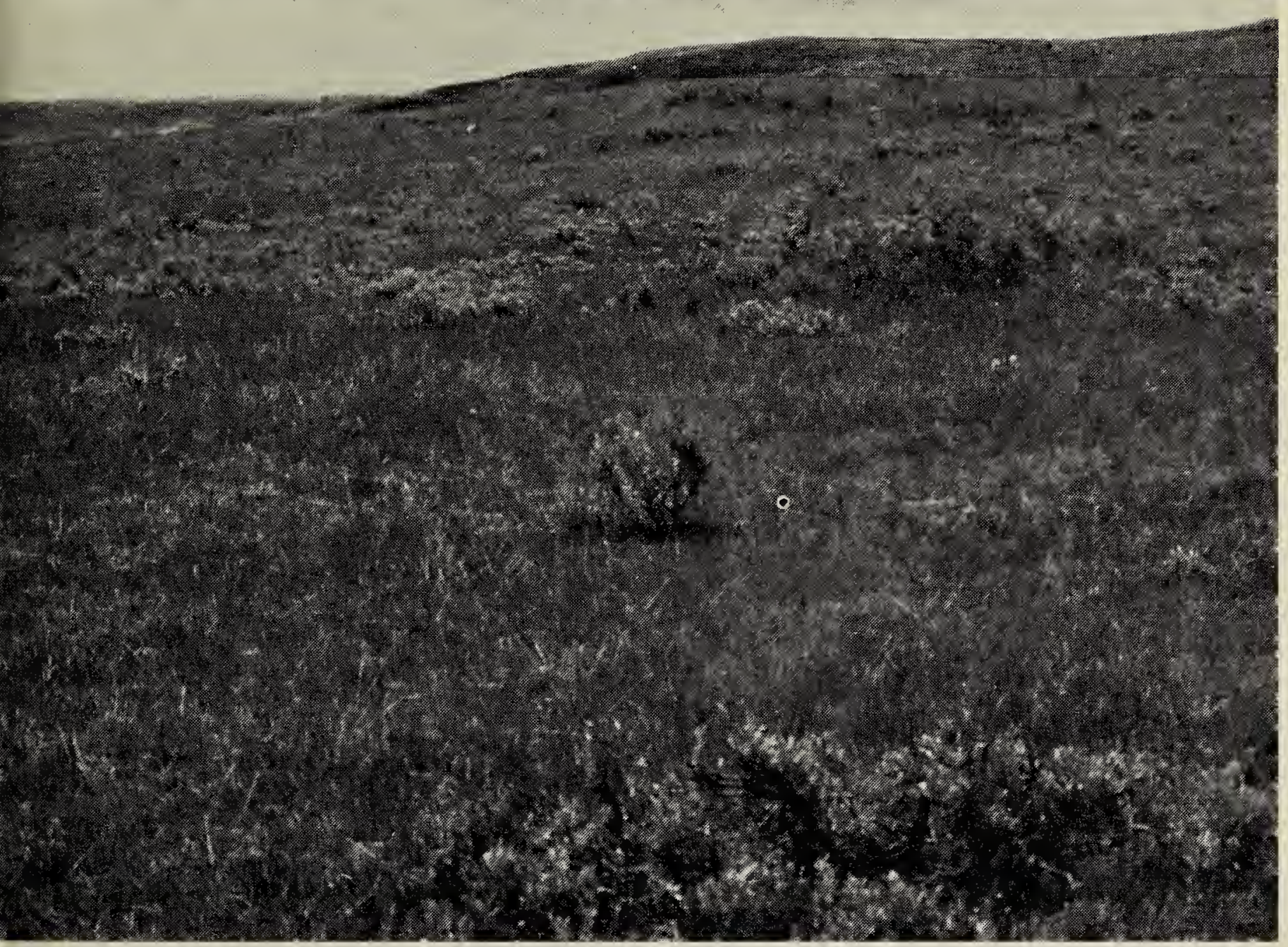

Figure 2. Habitat near the area where the ferret was seen.

ip of the tail was black. As it did not bok at me I did not notice a mask on he face.

Except for the woods in the coulee he area is mixed-grass prairie with hrubs (mainly Artemisia) (Figure 2), nd there are numerous ground quirrel burrows (probably Richardon's ground squirrel) dotting the illsides.

Not until later did I realize the ignificance of this sighting. Acording to Banfield the last Canadian pecimen of the black-footed ferret as taken in 1937 at Climax, Saskathewan, "... and the species is now believed to be extirpated in Canada."2 Anderson reported 22 records, including 11 specimens, from Saskatchewan between 1929 and 1937 , most of these from within 50 to $70 \mathrm{~km}$ of Eastend. ${ }^{1}$

I wish to thank Dr. J. R. Jowsey for his encouragement in publishing this note and Dr. R. E. Wrigley for making valuable suggestions.

'ANDERSON, R. M. 1946. Catelogue of Canadian Recent Mammals. Nat. Mus. Canada, Bull. No. 102, 238 pp.

2BANFIELD, A. W. F. 1974. The Mammals of Canada. Univ. of Toronto Press, Toronto, $438 \mathrm{pp}$. 